\title{
Bazal Ürik Asid Düzeyi, Sepsiste Akut Böbrek Hasarının Önceden Belirlenmesi İçin Bir Kılavuz Olabilir
}

\section{Baseline Serum Uric Acid Can Be a Guide for Predicting Acute Kidney Injury in Sepsis}

iD Hakk1 Y1lmaz ${ }^{1}$

${ }^{1}$ Sağlık Bilimleri Üniversitesi, Dr. Abdurrahman Yurtaslan Ankara Onkoloji Eğitim ve Araştırma Hastanesi, Nefroloji Bölümü, Ankara, Türkiye,

$\ddot{O} z$

Amaç: Sepsis, yoğun bakım ünitesinde (YBÜ), akut böbrek hasarının (ABH) en önemli nedeni olup \%15-20'sinde renal replasman tedavisi ihtiyacı olmaktadır. Ürik asit, hipertansiyon, dislipidemi, yağlı karaciğer, böbrek hastalıkları ve kardiyovasüler hastalıklarla ilişkilidir. Ürik asit seviyelerinin ABH riskinin artması ile bağlantılı olduğu gösterilmiștir. Biz de artmıș ürik asit düzeyinin ABH’yı önceden belirlemede rolü olup olmadığını incelemeyi amaçladık.

Gereç ve Yöntem: Bu retrospektif çalışmada, Eylül 2013-Aralık 2015 arasında sepsis nedeni ile YBÜ kabul edilen 105 ardışık hastayı dahil ettik. Kabul esnasındaki klinik laboratuvar testleri ve basitleştirilmiş akut fizyoloji skoru (SAPSII) kaydedildi ve 7 gün boyunca böbrek fonksiyonlarının izlemi yapıldı.

Bulgular: 7 gün içindeki $\mathrm{ABH}$ oluşum oranı \%47.6 idi. Bazal ürik asit düzeyi $\mathrm{ABH}$ gelişen grupta ABH gelişmeyen gruba göre daha yüksekti. Multivariate lojistik regresyon analizinde, serum ürik asit albumin ve SAPSII; ABH ile bağımsız olarak bağlantılıydı. Serum ürik asit 6.85 mg/dl eşik noktasında sepsis hastalarında ABH’yı belirlemede oldukça etkiliydi ve \%72 duyarlılık ve \%85.5 özgüllüğe sahipti. Sonuç: Artmış ürik asit düzeyi sepsiste ABH’nın önceden belirlenmesinde yardımcı olabilir.

Anahtar Sözcükler: Ürik asit, Akut böbrek hasarı, Sepsis

Abstract

Objective: Sepsis is the most important cause of acute kidney injury (AKI) in the intensive care unit (ICU) with $15 \%-20 \%$ of patients with sepsis-associated AKI prescribed renal replacement therapy. Uric acid has been linked to hypertension, dyslipidemia, fatty liver, renal disease, and cardiovascular disease. Uric acid levels are associated with an increased risk of AKI. Here, we explored whether elevated uric acid levels have a role in predicting AKI in sepsis.

Material and Method: This retrospective study enrolled 105 consecutive cases with sepsis admitted to the ICU in this retrospective study between September 2015 and December 2017. Clinical laboratory tests, and a new Simplified Acute Physiology Score (SAPSII) score were recorded on admission; renal function was monitored for seven consecutive days.

Results: The rate of AKI 7 days after enrollment was 47.6\%. Baseline uric acid levels were higher in the AKI group (Group 1) than in the non-AKI group (Group 2) (p $<0.001$ ). In multivariate logistic regression analysis, AKI was independently associated with serum uric acid, albumin, and SAPSII. Serum uric acid could effectively determine AKI in patients with sepsis at a cut-off point of $6.85 \mathrm{mg} / \mathrm{dl}$ including a sensitivity of $72.0 \%$ and a specificity of $85.5 \%$.

Conclusion: Elevated uric acid levels can help predict AKI in sepsis.

Keywords: Uric acid, Acute kidney injury, Sepsis

Yazışma Adresi: Hakkı Yılmaz, Sağlık Bilimleri Üniversitesi, Dr. Abdurrahman Yurtaslan Ankara Onkoloji Eğitim ve Araştırma Hastanesi, Nefroloji Bölümü E-Posta: drhakkiyilmaz@yahoo.com

Alınma tarihi: 26.07.2021 / Kabul tarihi: 26.07.2021 / Yayımlanma tarihi: 15.12.2021

Bazal Ürik Asid Düzeyi - Y1lmaz.

Genel Tip Derg 2021;31(4)391-395 


\section{Giriş}

Ürik asit insanlarda pürin baz metabolizmasının ksantin oksidaz ya da ksantin dehidrogenaz etkisiyle oluşan son ürünü olup günde oluşan üratın yaklaşık \%70'i böbreklerden; geri kalanı ise barsaklardan atılır (1). Serum ürik asit konsantrasyonu aşırı üretim, glomeruler filtrasyonun azalması, renal hipoperfüzyon, tübüler reabzorpsiyonda artış ya da atılımın azalması gibi bazı faktörlerden etkilenir. Birçok epidemiyolojik çalışmada hiperüriseminin hipertansiyon, kalp damar hastalıkları, diabetes mellitus, inme ve kronik böbrek hastalığının ilerlemesi ile ilişkili olduğu bildirilmiştir (2-6).

$\mathrm{ABH}$, beraberindeki mortalite ve morbiditeyle birlikte hastanede yatan hastalarda sık görülen bir komplikasyondur. Hastane kaynaklı ABH'nın insidansı epidemiyolojik çalışmalarda yaklaşık \%3-7 arasında olup yoğun bakım ünitesinde \%20-30'a çıkmaktadır; bu kişilerin \%6's1 renal replasman tedavisine gereksinim duymaktadır (79). Ek olarak, kalp damar cerrahisi öncesi hem düşük hem de yüksek serum ürik asit düzeyleri, postoperatif $\mathrm{ABH}$ için risk faktörüdür (10). Dahası, hastanede yatan hastalarda hiperürisemi ABH ile ilişkilidir (11). Sepsiste $A B H$ gelişmesi hasta morbiditesini artırır, daha yüksek mortaliteyi öngörür ve birçok organ fonksiyonu üzerinde önemli etkisi vardır. $\mathrm{Bu}$ çalışmada, sepsiste hiperüriseminin $\mathrm{ABH}$ gelişimi ile ilişkili olup olmadığını araştırdık.

\section{Gereç ve Yöntemler}

Bu retrospektif çalışmaya 19 Eylül 2013 ile 30 Aralık 2015 arasında üçüncü basamak dahiliye yoğun bakım ünitesine (DYBÜ) yatırılan $\geq$ 18 yaş hastalar dahil edildi. Çalışmaya dahil etme kriterleri yaşın $>18$ olması, DYBÜ'ne yatırılma nedeninin Yoğun Bakım Tıbı Derneğinin (Society of Critical Care Medicine) Sepsiste Sağ Kalım Kampanyası (Surviving Sepsis Campaign) 2012 tanımına göre araştırılmakta olan sepsis tanısı olmasıydı(12). Dâhil etmeme kriterleri yaşın $<18$ olması, önceden diyaliz ya da böbrek nakli öyküsü olması, böbrek hastalığı, gebe hastalar ve DYBÜ'ne yatırıldıktan sonra $<15$ gün içinde taburcu olan ya da ölen hastalardır. Çalışmaya başlamadan önce Klinik Araştırmalar Etik Kurulu'ndan 99950669/55 protokol numarasiyla etik kurul onay1 alınmıştır. Çalışmaya dâhil edilen tüm hastalardan Dünya Tıp Birliği Helsinki Bildirgesi'ne uygun yazılı bilgilendirilmiş onam alınmıştır.

ABH'yı tanımlamak üzere aşağıdakilerden en az üçünün var olduğu temeline dayanan KDIGO (evre 1) kriterlerini kullandık. Bunlar; (1) serum kreatinininde 48 saatte $\geq 0.3 \mathrm{mg} / \mathrm{dl}$ artış, (2) serum kreatinininde son 7 günde bazal değere göre $\geq 1.5$ kat artış ve (3) idrar çıkışının 6 saatte $<0.5 \mathrm{~mL} / \mathrm{kg} / \mathrm{saat}$ olmasidır (13).

Tüm değişkenler elektronik ve elle yazılmış klinik hasta kayıtlarından elde edilmiştir. Değişkenler hastaların demografik özellikleri (yaş, cinsiyet, etnik köken ve vücut ağırlığı), komorbiditeler, diabetes mellitus, hipertansiyon, kardiyovasküler hastalık (KVH), kronik obstrüktif akciğer hastalığı (KOAH), ilaçlar enfeksiyon odağ1 ve Basitleştirilmiş Akut Fizyolojik Skor II'ye (Simplified Acute Physiologic Score [SAPS] II) göre hastalık şiddetini içermektedir (14).

SAPS II skoru hastanın yatışından itibaren ilk 24 saat içinde yapılan 12 rutin fizyolojik ölçümdeki en kötü değerlere göre hesaplanmaktadır. SAPS II skoru aşağıdaki parametrelerden hesaplanmıştır; yaş, kalp atım hızı, sistolik kan basıncı, ateş, Glasgow Koma Skalası, mekanik ventilasyon ya da sürekli pozitif hava yolu basınc1 (CPAP), $\mathrm{PaO}_{2} / \mathrm{FiO}_{2}$, idrar çıkışı, üre, sodyum, potasyum, bikarbonat, bilirubin, lökosit sayısı, kronik hastalıklar ve yatış türü. YBÜ'ye yatıştan itibaren her hasta için aşağıdaki maddeler kaydedilmiştir; yaş, cinsiyet, vücut kitle indeksi, sigara içimi, serum kreatinin, üre, aspartat aminotransferaz (AST), alanin aminotransferaz (ALT), kalsiyum, $\mathrm{Na}, \mathrm{K}$, albümin, ürik asit, serum c-reaktif protein (CRP), idrar çıkışı ve MV (süresi). Ürik asit düzeyi yoğun bakımda takibe başlandığı anda elde edilen ilk verilerden yararlanılmıştır. Diabetes mellitus Amerikan Diyabet Cemiyeti kriterlerine (15) ve hipertansiyon Ortak Ulusal Komite'nin (Joint National Committee) yedinci bildirisine göre teşhis edildi (16). Serebrovasküler hastalık, kronik kalp yetmezliği, iskemik kalp hastalığı ya da periferik arteriyel hastalık öyküsü varlığında $\mathrm{KVH}$ var olarak kabul edilmiştir; KOAH, amfizem ve kronik bronşiti içermektedir. $\mathrm{KVH}, \mathrm{KOAH}$, diabetes mellitus ve hipertansiyon için klinik kayıtlarda önceden bir tanı bulunması yeterli kabul edilmiştir.

\section{İstatistik}

İstatistiksel analizlerde Windows için IBM SPSS Statistics 20.0 sürümü kullanılmıştır (IBM Corp., Armonk, NY, ABD). Sürekli değişkenler Kolmogorov-Smirnov testi ile yapılan analize göre belirlenen değişkenin dağılımına bağlı olarak ortalama \pm SS ya da medyan (çeyrekler arası genişlik, IQR) olarak verilmiştir. Kategorik değişkenler sayı ve yüzde olarak bildirilmiştir. Gruplar arasında kategorik değişkenlerin karşılaştırılmasında Ki-kare ya da Fisher'in kesin testi kullanılmıştır. Sürekli değişkenler Mann-Whitney U-testi ya da Student t-testi ile karşılaştırılmıştır. Serum ürik asit düzeyleri ile klinik parametreler arasındaki ilişkilerin belirlenmesinde Spearman ya da Pearson korelasyon katsayısı kullanılmıştır. Septik ABH gelişiminde risk faktörlerinin değerlendirilmesi için çok değişkenli lojistik regresyon analizi kullanılmıştır. Model kalibrasyonu anlamlılık için Hosmer-Lemeshow istatistik için uyumluluk testini kullanmıştır $(\mathrm{p}>0.05)$. Eşitsizlik oranları (EO) ve \%95 güven aralığı (GA) hesaplanmıştır. UA testinin sepsiste ABH'yı öngörmedeki geçerliliğinin belirlenmesinde ROC (alıcı işletim karakteristik) eğrisi kullanılmıştır. Sepsisi olan kritik hastalarda ürik asitin ABH'yı belirleyiciliği için önerilen kesim değeri Youden indeksine göre belirlenmiştir (17). p değerinin $<0.05$ olması istatistiksel anlamlı kabul edilmiştir.

\section{Bulgular}

Bu çalışmaya 105 hasta uygun bulunup çalışmaya dâhil edilmiştir. Tüm veriler hastalar çalışmaya alındıktan iki hafta sonra veri tabanından kaydedilmiştir. Kohort iki gruba ayrılmıştır. Grup $1(\mathrm{n}=50)$ ABH gelişen sepsis hastalarından oluşmakta, Grup $2(n=55)$ ABH gelişmeyen hastalardan oluşmaktadır. Popülasyonun ABH gelişimine göre demografik ve klinik özellikleri Tablo 1'de tanımlanmıştır. ABH gelişen hastalar KDIGO'ya göre evrelendiğinde $\% 46(n=23)$ hastada evre $1, \% 34(n=17)$ hastada evre 2 ve $\% 20(n=10)$ hastada evre 3 abh geliştiği görüldü.

İki grup arasında cinsiyet, vücut kitle indeksi, ALT, AST, Na, K ve CRP açısından anlamlı farklılıklar gözlenmemiştir. $\mathrm{ABH}$ olan hastaların SAPS II değerlerinin anlamlı şekilde daha yüksek olması $(37.7 \pm 13.52$ 'ye karş1 27.20 $\pm 9.60 ; \mathrm{P}=0.002)$ ve vazopressör ihtiyacı göstermesi daha olasıydı $(\mathrm{P}<0.001)$. Serum ürik asit seviyesi de (7.67 \pm 1.95 'e karş1 5.5 $\pm 1.2 ; \mathrm{P}=<0.001) \mathrm{ABH}$ olan hastalarda $\mathrm{ABH}$ olmayan hastalara göre daha yüksekti. Dahası, $\mathrm{ABH}$ hastalarında 
serum albümin değerleri daha düşük bulundu (3.21 \pm 0.51 'e karş1 $3.82 \pm 0.55 \mathrm{P}=0.043)$.

Serum ürik asit konsantrasyonları SAPS II skoruyla pozitif olarak korele bulundu (Pearson $r=0.707, P<0.0001$ ) (Şekil 1). Ürik asit düzeyleri ile kreatinin ya da estimated GFR arasında bir korelasyon tespit edilememiştir. Serum ürik asit seviyesi ile klinik parametreler arasında herhangi bir korelasyon yoktu.

ROC eğrisi analizinde ABH'yı belirlemede serum ürik asidin kesim değeri $\% 72.0$ duyarlılık ve $\% 85.5$ özgüllükle $6.85 \mathrm{mg} / \mathrm{dL}$ olarak bulunmuştur (AUC $=0.847, \% 95$ GA: 0.770-0.924) (Şekil 2).

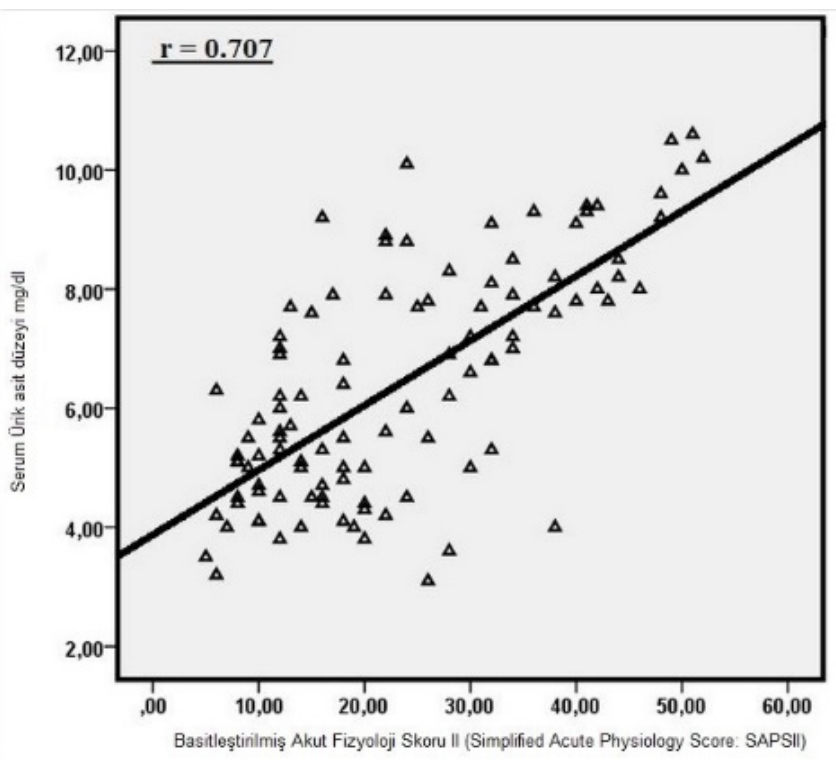

Şekil 1:

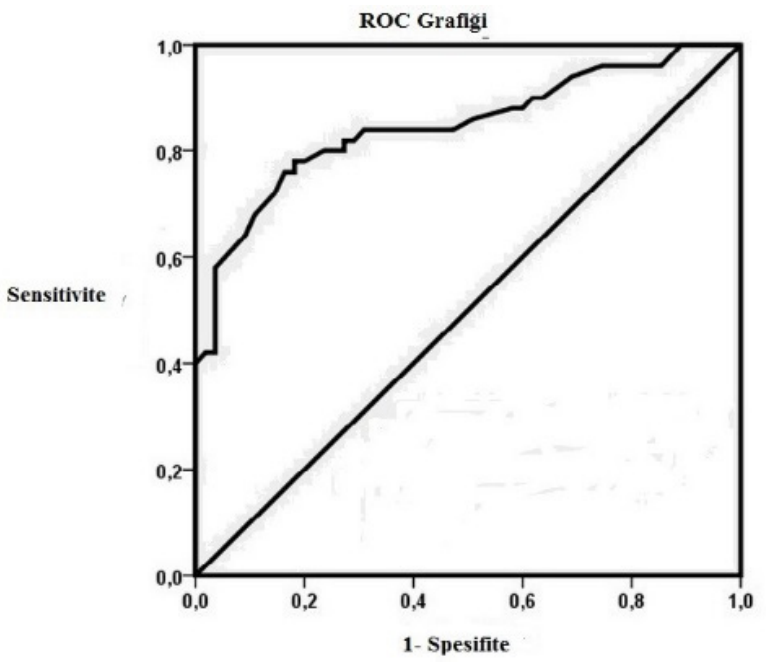

Şekil 2:

Lojistik regresyon analizinde SAPS II, albümin ve ürik asit sepsiste ABH gelişimiyle bağımsız olarak ilişkili bulunmuştur (Tablo 2).
Tablo 1. Sepsis hastalarının karakteristik özellikleri.

\begin{tabular}{|c|c|c|c|}
\hline & $\begin{array}{l}\text { Grup 1 } \\
{[\mathrm{ABH}, \mathrm{n}=50]}\end{array}$ & $\begin{array}{l}\text { Grup } 2[\mathrm{ABH} \\
\text { olmayan, } n=55]\end{array}$ & $\mathbf{P}$ \\
\hline Yaş, yl & $68.5 \pm 18.8$ & $59.2 \pm 16.5$ & $<0.001$ \\
\hline Cinsiyet (erkek), n (\%) & $22(44)$ & $24(43.6)$ & 0.819 \\
\hline Vücut kitle indeksi, $\mathrm{kg} / \mathrm{m}^{2}$ & $26.8 \pm 4.5$ & $25.9 \pm 4.9$ & 0.764 \\
\hline Tütün öyküsü, n (\%) & $13(26)$ & $14(25.4)$ & 0.328 \\
\hline Hipertansiyon, n (\%) & $28(56)$ & $31(56.36)$ & 0.724 \\
\hline Diabetes mellitus, $\mathbf{n}(\%)$ & $11(22)$ & $12(21.8)$ & 0.529 \\
\hline Kalp yetmezliği, n (\%) & $4(8)$ & $5(9.0)$ & 0.315 \\
\hline КОАН, n (\%) & $9(18)$ & $10(18.1)$ & 0.542 \\
\hline ACEİ/ARB, n (\%) & $24(48)$ & $22(40)$ & 0.073 \\
\hline \multicolumn{4}{|l|}{ Enfeksiyon kaynağı } \\
\hline Akciğer, n (\%) & $17(34)$ & $19(34.5)$ & 0.822 \\
\hline İdrar yolu, n (\%) & $13(26)$ & $14(25.4)$ & 0.614 \\
\hline İntra-abdominal, $\mathbf{n}(\%)$ & $10(20)$ & $11(20)$ & 1.000 \\
\hline Diğer, n (\%) & $10(20)$ & $11(20)$ & 1.000 \\
\hline Bazal SAPSII & $37.7 \pm 13.52$ & $27.20 \pm 9.60$ & $<0.001$ \\
\hline $\begin{array}{r}\text { Bazal invazif mekanik } \\
\text { ventilasyon durumu, } \mathrm{n}(\%)\end{array}$ & $24(35.2)$ & $16(32)$ & 0.095 \\
\hline $\begin{array}{l}\text { invazif mekanik ventilasyon } \\
\text { süresi, saat }\end{array}$ & $122(98)$ & $110(101)$ & 0.134 \\
\hline \multicolumn{4}{|l|}{ Kabul anında Laboratuvar verileri } \\
\hline kreatinine, $\mathbf{m g} / \mathbf{d L}$ & $0.86 \pm 0.24$ & $0.83 \pm 0.20$ & 0.623 \\
\hline International normalized ratio & $1.1 \pm 0.4$ & $1.09 \pm 0.5$ & 0.479 \\
\hline aPTT, s & $45(35)$ & $42(31)$ & 0.387 \\
\hline ALT, U/L & $60 \pm 42$ & $58 \pm 43$ & 0.271 \\
\hline AST, U/L & $56 \pm 40$ & $53 \pm 42$ & 0.527 \\
\hline Total bilirubin, $\mathrm{mg} / \mathrm{dL}$ & $1.6 \pm 1.1$ & $1.7 \pm 0.9$ & 0.625 \\
\hline $\mathrm{Ca}, \mathrm{mg} / \mathrm{dL}$ & $9.0 \pm 0.7$ & $9.1 \pm 0.8$ & 0.807 \\
\hline $\mathrm{Na}, \mathrm{mEq} / \mathrm{L}$ & $139 \pm 5.8$ & $140 \pm 6.1$ & 0.355 \\
\hline $\mathbf{K}, \mathbf{m E q} / \mathbf{L}$ & $4.32 \pm 0.85$ & $4.21 \pm 0.92$ & 0.803 \\
\hline Albumin, $\mathbf{g} / \mathbf{d L}$ & $3.21 \pm 0.51$ & $3.82 \pm 0.55$ & 0.043 \\
\hline Ürik asid, mg/dL & $7.67 \pm 1.95$ & $5.5 \pm 1.2$ & 0.001 \\
\hline $\mathrm{CRP}, \mathrm{mg} / \mathrm{L}$ & $218(105)$ & $222(110)$ & 0.426 \\
\hline
\end{tabular}

KOAH: Kronik obstrüktif akciğer hastalığı, aPTT:

Aktive parsiyel tromboplastin zaman1, ACEİ: Anjiotensin Konverting Enzim İnhibitörleri, ARB: Anjiotensin Reseptör Bloke Edici Ajanlar, ALT: Alanin Aminotransferaz,AST: Aspartat Aminotransferaz, Ca: Kalsiyum, Na: Sodyum, K: Potasyum, CRP: C-reaktif protein

Tablo 2. Sepsis hastalarında ABH'yı öngörmede bağımsız risk faktörlerini belirlemek için Multivariate Lojistik analiz yapıldı.

\begin{tabular}{lllll}
\hline & $\begin{array}{l}\text { Univariate (OR, } \\
\mathbf{9 5 \%} \text { CI) }\end{array}$ & $\mathbf{P}$ & $\begin{array}{l}\text { Multivariate (OR, } \\
\mathbf{9 5 \%} \text { CI) }\end{array}$ & P \\
SAPS II & $3.68(2.15-5.28)$ & $<0.001$ & $2.97(1.89-6.24)$ & 0.02 \\
Albumin & $0.78(0.72-0.84)$ & $<0.001$ & $0.89(0.72-1.23)$ & 0.07 \\
Ürik asid & $5.12(2.95-8.79)$ & $<0.001$ & $5.08(1.9-15.2)$ & $<0.001$ \\
\hline
\end{tabular}

SAPS II: Basitleştirilmiş Akut Fizyolojik Skor II (Simplified Acute Physiologic Score II) 


\section{Tartışma}

Bu retrospektif çalışmada, sepsiste olan MYBÜ'ye yatan hastalarda ürik asit düzeylerindeki artışın $\mathrm{ABH}$ gelişimiyle ilişkili olduğu tespit edilmiştir. ABH'nın etyolojisi geniş bir spektrumdadır ve iskemik/ hipoksik, nefrotoksik ve inflamatuvar etkenleri içeren birçok mekanizma $\mathrm{ABH}$ gelişimine katkıda bulunur. $\mathrm{ABH}$, septik hastaların kabaca \%35'inde gelişir ve YBÜ'deki genel ABH insidansı yaklaşık \%50'yi bulmaktadır (18). Dahası, ağır ABH ile ilişkili hastane içi mortalite, septik hastalarda septik olmayan hastalara göre anlamlı olarak daha yüksektir (\%70.2'ye karş1 \%51.8) $(9,18)$.

Sepsiste ürik asit artışının mekanizması halen bilinmemektedir ve ürik asid üretiminin artması ya da atılımının azalmasına bağlı olabilir. İskemi ya da hipoksi ağır sepsisle ve birçok organdaki septik şokla uyarılabilir; bu da mikravasküler endotelde ksantin oksidazın aktivasyonu aracılığıyla ksantin/hipoksantinin ürik aside değişimini daha da artırır $(19,20)$. Böylece, ürik asit üretiminde artmış olur. Hiperürisemi eNOS ekspresyonunu azaltarak ve inflammatuvar sitokinler (IL-6 ve TNF- $\alpha$ ) ile adezyon moleküllerinin (ICAM-1 ve VCAM-1) düzeyini artırarak NO üretimini azaltır $(21,22)$. Endotel vasküler tonusu düzenlemez. Bu olaylar bir dizi patofizyolojik sürece ve böbrek de dâhil olmak üzere iç organların disfonksiyonuna yol açar (23).

Birkaç mekanizma nedeniyle ürik asit ABH'ya yol açabilir. Bunlar içinde kristalle indüklenen hasardan dolayı direk tübüler toksisiteden vazoaktif aracıların salınması ve oksidatif stres ile sekonder hasara kadar değişebilir $(23,24)$. Ürik asit renin-anjiotensin sisteminin aktivasyonuna, katekolamin salınımına, oksidatif strese, proinflamatuvar belirteçlerin salınımına ve azalmış nitrik oksit düzeylerine yanıt olarak gelişen renal vazokonstrüksiyon aracılığı ile ABH'ya yol açabilir(25). ABH'nın deneysel modelinde artmış serum ürik asidi lökosit infiltrasyonuyla birlikte kemokin ekspresyonunu içeren proinflamatuvar yolaklarla renal hasarı daha da artırmaktadır $(26,27)$. Bu nedenle sepsisi olan hastalarda $\mathrm{ABH}$ riski üzerine bazal SUA'nın potansiyel etkisini araştırdık.

Ürik asit endotelyal disfonksiyon, vazokonstrüksiyon, oksidatif stres ve intra-tübüler obstrüksiyon ile böbrek hasarına yol açabilir. Bu nedenle, ürik asit septik hastalarda $\mathrm{ABH}$ riskini öngörebilir. Sepsiste ABH gelişmesi hastane içi ölüm riskinde bağımsız ve önemli bir artışa neden olur ve uzamış YBÜ ve hastane yatışı ile ilişkilidir. Artmış serum ürik asidi ve sepsis prognozu arasında ilişki bulunmamıştır; ancak hiperürisemi SAPS II ile koreledir ve YBÜ hastalarında sepsisin şiddetini puanlamak için kullanılmıştır. Benzer şekilde, birçok çalışmada serum ürik asit düzeylerinin sepsisin şiddetini ve prognozunu yansitabileceği bildirilmiştir(28-30).

Kardiyovasküler cerrahi ve kardiyak kateterizasyon sırasında ameliyat öncesi yüksek serum ürik asit düzeyinin ameliyat sonrası ABH ile ilişkili olduğu bildirilmiştir (10,31-32). Dahası, artmış serum ürik asit düzeyleri kontrast maddenin neden olduğu $\mathrm{ABH}$ riskini de artırır $(33,34)$. Bu çalışmalar bizim çalışmamızla uyumludur ve artmış serum ürik asit seviyesinin sepsiste ABH'yı öngörebileceğini göstermektedir.

$\mathrm{Bu}$ çalışmanın bazı sınırlılıkları vardır. Birincisi, retrospektif tek merkezli çalışmaların doğasından kaynaklanan sonuçlarla ilişkili kısıtll1ıklardır. İkincisi, çalışmamızın örneklem büyüklüğü görece olarak küçüktür. Daha fazla denek olması sonuçların daha fazla genellenebilmesine olanak sağlardı ve doğruluğunu artırırdı. Üçüncüsü, sepsiste hiperürisemi ve $\mathrm{ABH}$ arasında neden-sonuç ilişkisini kurmak mümkün olmamıştır. Diğer olası kısıtllılıklar arasında hastaları yalnızca 7 gün izlemiş olmamız ve hastanın durumunu yansitabilecek potansiyel değişikliklerin olup olmadığını göstermek üzere ürik asit değerlerini takip etmemiş olmamız bulunmaktadır. Akut Fizyoloji ve Kronik Sağlık Değerlendirmesi II (The Acute Physiology and Chronic Health Evaluation II [APACHE II]) YBÜ'lerde hastalık ağırlığını puanlamak için en sık kullanılan sistemdir; ancak biz APACHE sistemi yerine 1984'te tanımlanan SAPS II'yi kullandık.

\section{Sonuç}

Serum ürik asit düzeyleri, sepsisteki hastalarda ABH'yı öngörmede yararlı bir biyobelirteç olabilir.

\section{Tasdik ve Teşekkür}

Yazarlar arasında çıkar çatışması tarif eden herhangi bir kişi bulunmamaktadır. Bu çalışmada herhangi bir fon veya destekten yararlanılmamıştır. Yoğun bakım hastalarının takibinde katkısı olan Enfeksiyon hastalıkları, Anestezi ve Reanimasyon ve İç Hastalıkları bölümüne ve çalışanlarına teşekkür ediyorum.

\section{Kaynaklar}

1.Edwards NL. The role of hyperuricemia and gout in kidney and cardiovascular disease. Cleve Clin J Med. 2008;75(Suppl 5):13-6.

2.Johnson RJ, Segal MS, Srinivas T, et al. Essential hypertension, progressive renal disease, and uric acid: a pathogenetic link? J Am Soc Nephrol. 2005;16(7):1909-19.

3.Jee SH, Lee SY, Kim MT. Serum uric acid and risk of death from cancer, cardiovascular disease or all causes in men. Eur J Cardiovasc Prev Rehabil. 2004;11(3):185-91.

4.Lytvyn Y, Perkins BA, Cherney DZ. Uric acid as a biomarker and a therapeutic target in diabetes. Can J Diabetes. 2015;39(3):239-46.

5.Bos MJ, Koudstaal PJ, Hofman A, Witteman JC, Breteler MM. Uric acid is a risk factor for myocardial infarction and stroke: the Rotterdam study. Stroke. 2006;37(6):1503-7.

6.Madero M, Sarnak MJ, Wang X, et al: Uric acid and long-term outcomes in CKD. Am J Kidney Dis. 2009;53:796-803.

7.Fang Y, Ding X, Zhong Y, et al. Acute kidney injury in a Chinese hospitalized population. Blood Purif. 2010;30(2):120-6.

8.Nash K, Hafeez A, Hou S. Hospital-acquired renal insufficiency. Am J Kidney Dis. 2002;39(5):930-6

9.Uchino S. The epidemiology of acute renal failure in the world. Curr Opin Crit Care. 2006;12(6):538-43.

10.Lapsia V, Johnson RJ, Dass B, et al. Elevated uric acid increases the risk for acute kidney injury. Am J Med. 2012;125(3):302.e9-17.

11.Otomo K, Horino T, Miki T, et al. Serum uric acid level as a risk factor for acute kidney injury in hospitalized patients: a retrospective database analysis using the integrated medical information system at Kochi Medical School hospital. Clin Exp Nephrol. 2016;20(2):235-43.

12.Dellinger RP, Levy MM, Rhodes A, et al; Surviving Sepsis Campaign Guidelines Committee including the Pediatric Subgroup. Surviving sepsis campaign: international guidelines for management of severe sepsis and septic shock: 2012. Crit Care Med. 2013;41(2):580-637.

13.The Kidney Disease Improving Global Outcomes (KDIGO) Working Group. KDIGO clinical practice guideline for acute kidney injury. Kidney Int Suppl. 2012;2(Suppl 1):1138

14.Le Gall JR, Lemeshow S, Saulnier F. A new Simplified Acute Physiology Score (SAPS II) based on a European/North American multicenter study. JAMA. 1993;270:2957-63

15.ADA. Standards of medical care in diabetes - 2009. Diabetes Care. 2009;32(Suppl 1):13-61.

Bazal Ürik Asid Düzeyi - Yılmaz. 
16.Chobanian AV, Bakris GL, Black HR, et al. The seventh report of the Joint National Committee on prevention, detection, evaluation, and treatment of high blood pressure: the JNC 7 report. JAMA. 2003;289(19):2560-72.

17. Youden, WJ. Index for rating diagnostic tests. Cancer. 1950;3(1):32-5.

18.Doi K. Role of kidney injury in sepsis. J Intensive Care. 2016;4:17. doi: 10.1186/ s40560-016-0146-3.

19.Meneshian A, Bulkley GB. The physiology of endothelial xanthine oxidase: from urate catabolism to reperfusion injury to inflammatory signal transduction. Microcirculation. 2002;9(3):161-75.

20.Terada LS, Guidot DM, Leff JA, et al. Hypoxia injures endothelial cells by increasing endogenous xanthine oxidase activity. Proc Natl Acad Sci USA. 1992;89(8):3362-6.

21.Khosla UM, Zharikov S, Finch JL, et al. Hyperuricemia induces endothelial dysfunction. Kidney Int. 2005;67(5):1739-42.

22.Cai W, Duan XM, Liu Y, et al. Uric acid induces endothelial dysfunction by activating the HMGB1/RAGE signaling pathway. Biomed Res Int. 2017;2017:4391920. doi: $10.1155 / 2017 / 4391920$.

23.Hahn K, Kanbay M, Lanaspa MA, Johnson RJ, Ejaz AA. Serum uric acid and acute kidney injury: A mini review. J Adv Res. 2017;8(5):529-36.

24.Kaushik M, Choo JC. Serum uric acid and AKI: is it time? Clin Kidney J. 2016;9(1):4850 .

25.Sánchez-Lozada LG, Tapia E, Santamaría J, et al. Mild hyperuricemia induces vasoconstriction and maintains glomerular hypertension in normal and remnant kidney rats. Kidney Int. 2005;67(1) 237-47.

26.Roncal CA, Mu W, Croker B, et al. Effect of elevated serum uric acid on cisplatininduced acute renal failure. Am J Physiol Renal Physiol. 2007;292(1):F116-22.

27.Mazzali M, Hughes J, Kim YG, et al. Elevated uric acid increases blood pressure in the rat by a novel crystal-independent mechanism. Hypertension. 2001;38(5):1101-6.

28.Akbar SR, Long DM, Hussain K, et al. Hyperuricemia: an early marker for severity of illness in sepsis. Int J Nephrol. 2015;2015:301021. doi: 10.1155/2015/301021.

29.MacKinnon KL, Molnar Z, Lowe D, Watson ID, Shearer E. Measures of total free radical activity in critically ill patients. Clin Biochem. 1999;32(4):263-8.

30.Tsai K, Hsu T, Kong C, Lin K, Lu F. Is the endogenous peroxyl-radical scavenging capacity of plasma protective in systemic inflammatory disorders in humans? Free Radic Biol Med. 2000;28(6):926-33.

31.Gaipov A, Solak Y, Turkmen K, Toker A, Baysal AN, Cicekler H. Serum uric acid may predict development of progressive acute kidney injury after open heart surgery. Ren Fail. 2015;37(1):96-102.

32.Ejaz AA, Beaver TM, Shimada M, Sood P, Lingegowda V, Schold JD. Uric acid: a novel risk factor for acute kidney injury in high-risk cardiac surgery patients? Am J Nephrol. 2009;30(5):425-29.

33.Mendi MA, Afsar B, Oksuz F, Turak O, Yayla C, Ozcan F. Uric acid is a useful tool to predict contrast-induced nephropathy. Angiology. 2017;68(7):627-32.

34.Park SH, Shin WY, Lee EY, Gil HW, Lee SW, Lee SJ. The impact of hyperuricemia on in-hospital mortality and incidence of acute kidney injury in patients undergoing percutaneous coronary intervention. Circ J. 2011;75(3):692-97. 